\title{
Porque o calor dos braços teus traz-me de volta: 0 revisionismo dos contos de fadas na narrativa fílmica Frozen
}

\author{
Fernanda L. de Oliveira Santos ${ }^{1}$ \\ Silvana Augusta Barbosa Carrijo² \\ [Recibido, 26 setembro 2016; aceptado, 2 marzo 2017] \\ http://dx.doi.org/10.15304/bgl.51.3236
}

RESUMO Pelo presente estudo, objetivamos tecer reflexões acerca do longa-metragem de animação Frozen (2013), dirigido por Chris Buck e Jennifer Lee, produzido pela Walt Disney Pictures, de modo a compreendê-lo como uma releitura do conto $A$ rainha da nevedo escritor dinamarquês Hans Christian Andersen (1981), e verificar as principais instâncias que imprimem à narrativa fílmica aspectos revisionistas.

PalAVRAs-CHAVE: Conto de Fadas, Cinema, Frozen.

ABSTRACT In the present study, we set out to reflect on the animated feature film Frozen (2013), directed by Chris Buck and Jennifer Lee, produced by Walt Disney Pictures, in order to understand it as a retelling of the tale The Snow Queen of the writer Danish Hans Christian Andersen (1981), and to verify the main instances that print to the narrative film revisionist aspects.

KEYWORDS: Fairy Tale, Cinema, Frozen.

\section{Manifestações do 'era uma vez...'}

O fascínio exercido pelo processo de narração de histórias, desde tempos imemoriais, é inegável na trajetória da humanidade. Os contos de fadas, inseridos nesse processo, fascinam desde tempos anteriores a seu registro escrito por Charles Perrault, em 1697, com os Contos da mamãe Gansa, em Paris, e até hoje suscitam fantasias do nosso imaginário. Os acontecimentos históri-

1 Mestre em Estudos da Linguagem pela Universidade Federal de Goiás - Regional Catalão (UFG) $\mathrm{RC})$.

2 Professora Doutora Adjunta da Unidade Acadêmica Especial de Letras e Linguística, da Universidade Federal de Goiás - Regional Catalão (UFG/RC)... 
cos nos provam que essa forma de narrativa, nascida na antiga tradição oral, percorreu longa trajetória até se consolidar como textos clássicos ocidentais transcritos por autores como Perrault e os Irmãos Grimm. Após séculos de existência, o gênero tem experimentado novas formas de existência, absorvendo a sofisticação tecnológica de que dispõe o mundo contemporâneo. Ultrapassando as barreiras institucionalizadas dos livros, os contos de fadas têm conquistado novos suportes para sua produção e circulação, tornando possível o acesso a outras formas de representações estéticas, quais sejam, as modalidades ligadas à comunicação pela imagem, propiciada pela técnica da transposição fílmica que potencialmente podem alcançar um grande público, atendendo, ao lado da literatura, à necessidade de satisfação de ficção e fantasia tão comum aos indivíduos.

É inegável que, dentre as conquistas humanas, a evolução dos meios de comunicação bem como o desenvolvimento das novas tecnologias da informação consistem num grande salto no âmbito das transformações técnicas e científicas ocorridas a partir do século XIX. O cinema, assim como a literatura, opera como um 'contador de histórias', e assume papel importante nas formas de narrar, como o fez desde seu surgimento, na França, em meados dos anos de 1895. O encantamento suscitado pelas histórias contadas através das telas ainda hoje causa fascínio, talvez pela enorme gama de recursos tecnológicos que contribuem para superproduções recheadas de efeitos especiais que conferem ainda mais magia às histórias apresentadas. Cabe salientar, contudo, que a fantasia suscitada no imaginário através do cinema parece independer dos recursos dispostos pela modernidade. Ao pesquisarmos sobre os dados históricos que dão conta da origem do cinema, deparamo-nos com registros que comprovam o encanto exercido por esse suporte, desde sua criação. Robert Stam, crítico e teórico que se dedicou aos estudos sobre o gênero, ressalta que, nos primeiros escritos sobre a sétima arte, é possível encontrarmos um discurso de fascinação, "uma espécie de reverência religiosa pela pura magia da mimese, pela simples visão de uma representação-simulacro convincente da chegada de um trem ou do "vento soprando a folhagem” (Stam 2003: 38). Tendo surgido na França, em 1895, o Cinema tem como pioneiros os irmãos Louis e Auguste Lumière, responsáveis por exibir a primeira película de celuloide num projetor de manivela, denominado $c i$ nematógrafo - registrador de movimentos (do grego: kinema + grafein) - que serviu para gravar imagens de figuras em movimento e, posteriormente, para projetar imagens. Ainda que se tratasse de uma sequência, em preto e bran- 
co e sem a ausência de som, de uma cena corriqueira em que funcionários deixavam uma fábrica ao final de um dia de trabalho, foram essas as imagens que inauguraram o universo da magia cinematográfica através da imagem em movimento. Posteriormente, sons, imagens, linguagens verbais e não verbais a serviço da ilusão provocada pelo movimento na tela, conferiram ao cinema o status de 'sétima arte', a primeira forma artística original do século XX que recebe, desde sua criação, o bônus de uma tecnologia em constante evolução operando para produções cada vez mais sofisticadas no trabalho com representações. Dentre as perspectivas várias e frente aos vários paradigmas teóricos por meio dos quais é possível estudar o cinema enquanto obra de arte, nossa análise privilegiará os mecanismos pelos quais a sétima arte revisa certos contos de fadas clássicos e as implicações dessa produção enquanto forma de entretenimento.

Pensar o entrecruzamento entre duas diferentes artes que contam histórias inclui refletir sobre produções, consumos, prazeres e significados contidos nas histórias criadas como textos primeiramente orais e depois impressos e, posteriormente, naquelas que são recriadas do papel para a tela. Isso implica também pensamentear a nossa própria cultura, de modo a refletir sobre como ela está sendo representada e que leituras os contos de fadas originais e/ou (re)criados pelo cinema podem ensejar. Encontrando na literatura, e mais especificamente nas narrativas ligadas ao imaginário, como os contos de fadas, matéria-prima para suas (re)criações, o cinema nos leva a vivenciar um momento em que a diversidade de filmes que compõem o acervo do mercado cultural ocidental impressiona, principalmente no que tange aos filmes potencialmente dirigidos a crianças e jovens, e até mesmo a adultos, como produto de releituras de contos de fadas. A recriação, muitas vezes, aparece por meio do cinema de animação, cuja obra inaugural realizada por um expressivo estúdio tratava-se justamente de um conto de fadas da literatura clássica ocidental, Branca de Neve, produzido pelos estúdios Disney em 1937.

Carolina Marinho (2011), pesquisadora de narrativas maravilhosas provenientes da literatura e do cinema, observa que desde os anos iniciais de 1900, muitos clássicos da literatura universal foram transmutados nas telas em obras de grande sucesso, responsáveis por uma vertente definitiva que marcaria os novos rumos da história do cinema. A autora nos informa, ainda, que Griffith - um dos maiores realizadores do cinema norte-americano - foi o primeiro a levar às telas histórias de escritores consagrados como Shakespe- 
are, Poe, Dickens, entre outros, lançando as sementes para a legitimação do cinema no rol das 'belas-artes' e consolidando sua ligação com a arte literária.

Em terrenos do cinema de animação, a busca pela inspiração não se deu de forma de diferente. Segundo Sue Short (en Martins 2015: 279) "o interesse da indústria cinematográfica pela adaptação de contos de fadas é evidente desde os primórdios do cinema, quando os produtores de filmes foram atraídos pela familiaridade do material, sua propensão para encenar um espetáculo visual, e seu potencial de atrair a atenção em geral. Ao investigarmos o modo como versões cinematográficas de contos de fadas retomam tais e narrativas clássicas, salta aos olhos o caráter inovador com que esse processo ocorre. É o que pretendemos observar no longa-metragem Frozen (2013), uma narrativa de animação que se inspira no antigo conto de Hans Christian Andersen, A rainha da neve (1844) ${ }^{3}$, de modo a representar, de certa forma, uma versão atualizada e revisionista desta história.

Partindo da hipótese de que os contos de fadas têm assumido um caráter menos 'autoritário' e mais inovador quando relidos e revistos à luz das contemporâneas versões cinematográficas, procuraremos ${ }^{4}$ asseverar como tais versões conservam todo o ludismo presente nas histórias clássicas que lhes subsidiam como fonte. A análise nos permite compreender como tais narrativas fomentam as possibilidades de desconstrução de visões cristalizadas de valores e ideologias, vez que representam, por meio do conto de fadas, possibilidades mais abertas e variadas de se representar subjetividades através da fantasia. O que nos atrai ao analisarmos uma narrativa fílmica de animação como Frozen vai além de um olhar meramente estético que procura apenas medir as diferenças existentes entre obra inspirada e inspiradora.

\section{No reino do 'já estive lá’...}

As questões colocadas anteriormente consistem na tentativa de explanar, ainda que tangencialmente, as origens do conto de fadas e do cinema bem

3 Para o presente estudo, utilizamo-nos da edição datada de 1981, conforme informada nas Referências Bibliográficas deste texto.

4 O presente artigo é produto de pesquisa em nível de mestrado desenvolvida no Programa de Pós-graduação em Estudos da Linguagem, pela Universidade Federal de Goiás - Regional Catalão - GO (Brasil), sob orientação da Profa. Dra. Silvana Augusta Barbosa Carrijo. A pesquisa contou com bolsa da agência de fomento Capes - Coordenação de Aperfeiçoamento de Pessoal de Nível Superior - Brasil. 
como o percurso destas artes até os dias atuais, revelando a existência do entrecruzamento entre histórias que saíram do papel para a tela, inspiradas em obras do gênero conto de fadas. Entretanto, antes de levarmos adiante a análise a que nos propomos, faz-se pertinente que esclareçamos que a produção cinematográfica selecionada para apreciação neste trabalho insere-se em contexto histórico e cultural digno de nota neste texto.

A pós-modernidade, que posiciona as manifestações artísticas da contemporaneidade em um lugar de contestação e problematização, traz consigo o que estudiosos como Frederic Jameson (1982: 12) denominam como "um conceito de periodização cuja principal função é correlacionar a emergência de novos traços formais na vida cultural com a emergência de um novo tipo de vida social e de uma nova ordem econômica". Esse cenário nos faz entender que o modo como temos nos organizado social e culturalmente na atualidade abre espaço para variadas manifestações que, segundo o autor, seriam responsáveis pela dissolução de algumas fronteiras e divisões entre, por exemplo, cultura erudita e cultura popular (a dita cultura de massa). Nessa perspectiva de Jameson, podemos afirmar que a incorporação dos clássicos pelo cinema dilui, cada vez mais, as fronteiras outrora estabelecidas entre a arte erudita e as outras formas que se vêm, pois, hibridizadas.

Não é de nossa pretensão discutir, nos limites deste texto, os conceitos vários atribuídos à pós-modernidade e nem dizer das inúmeras controvérsias entre as diferentes abordagens realizadas nesse sentido por diferentes autores, para muitos dos quais essa visada epistemológica seria até mesmo questionável. Porém, o que nos faz recorrer a esse viés teórico é a tentativa de dizer do sincretismo comum ao estilo artístico cultural existente na contemporaneidade e da recorrência de recursos como paródias, pastiches, intertextualidades e adaptações que mantêm diálogo com obras já existentes, ainda que se recusando a propor qualquer estrutura ou qualquer narrativa mestra, a exemplo do que parece ocorrer com nosso objeto. Isso seria o que Robert Stam (2011) denomina 'liberalismo de estilos', ocasionando um remapeamento de possibilidades que abrangem descentramentos ou deslocamentos - sugestivos das desmistificações dos paradigmas preexistentes. Além disso, para Stam, o pós-modernismo sugere abertura, multiplicidade, pluralidade e hibridismo, sugerindo inclusive que o cinema pós-moderno tornou-se estilisticamente híbrido ao passo que combina referências às mais diversas fontes possíveis, formando um jogo lúdico que se estabelece com o espectador por 
meio de um cinema recombinante. Em uma era de remakes, sequências e revisitações, parecemos estar no reino do 'já se esteve lá. Levando em conta esse contexto, interessa-nos observar o que resulta dessa hibridização de linguagens, transformações e transmutações entre diferentes meios que se recombinam para que nossas percepções se alterem, fazendo com que tenhamos novas apreensões do mundo.

Nessa perspectiva, nosso interesse reside na mudança ou reinvenção das histórias e seus personagens que, na interface entre cinema e literatura, asseguram a perenidade dos contos de fadas, que vão se adaptando para o tempo e espaço atuais. Reconfiguradas, adaptadas através da narrativa simples ou valendo-se de outros meios, como o cinematográfico, essas histórias continuam contribuindo para a formação do imaginário coletivo, para a propagação dos contos e de toda a significação que trazem consigo. É também nesse sentido que consideramos válido salientar que não nos aprofundaremos, nesta análise, nas questões teóricas que discutam enfaticamente assuntos referentes à adaptação e suas implicações, tradução intersemiótica, fidelidade do novo texto ao texto predecessor ou mesmo da possiblidade de hierarquia entre uma arte e outra. Entretanto, é importante mencionarmos a intertextualidade como o conceito do qual nos aproximamos para embasar nossas discussões ao consideramos que este, conforme pondera Robert Stam (2011:227) "é um conceito teórico valioso, na medida em que relaciona o texto individual particularmente a outros sistemas de representação, e não a um mero e amorfo contexto".

Para que possamos compreender com mais clareza as relações intertextuais existentes entre o objeto de nossa análise e a narrativa de Andersen, não podemos prescindir de buscar como aporte teórico as considerações de Gérard Genette em Palimpsestes (1982)5. Neste estudo, o autor francês discute a transtextualidade, ou transcendência textual, como "tudo que coloca o texto em relação manifesta ou secreta com outros textos" (Genette 1982: 7). Ao desenvolver este conceito, o estudioso francês repertoria predicamentos da transtextualidade estabelecendo uma tipologia para cinco categorias gerais de que cada texto procede. O primeiro deles seria a intertextualidade, um empréstimo não declarado, segundo palavras do próprio autor; a relação de co-presença entre dois ou vários textos, o que estaria ligado às práticas de

5 Neste trabalho, utilizaremos a versão traduzida no Brasil em 2006. 
citação, plágio, alusão e a relação das obras que precedem ou sucedem um texto. O segundo tipo seria constituído pela relação menos explícita que o texto mantém com o que se pode apenas designar como seu paratexto - título, subtítulo, intertítulos, prefácios, posfácios, advertências, prólogos, etc., resultando no processo da paratextualidade. O terceiro tipo, denominado metatextualidade, descreve a relação crítica que une um texto ao outro, explícita ou silenciosamente, numa espécie de comentário que os une. O quinto tipo constitui a arquitextualidade, que determina o estatuto genérico do texto. Este é, segundo Genette, o tipo mais abstrato e o mais implícito da relação entre textos.

Adiamos a referência ao quarto tipo repertoriado por Genette, o da bipertextualidade, para nos atermos com maior atenção a ele, por julgá-lo como o mais sugestivo para a análise fílmica. Conforme pondera Robert Stam (2011: 234), o termo 'hipertextualidade' possui uma rica aplicação potencial para o cinema, pois pode ser aplicado para dizer das relações entre as adaptações cinematográficas e os textos originais, "em que as primeiras podem ser tomadas como hipertextos derivados de hipotextos preexistentes, transformados por operações de seleção, amplificação, concretização e atualização".

Vale ressaltar que a teoria da intertextualidade foi introduzida por Julia Kristeva na década de 1960 com pressupostos na teoria do dialogismo de Bakhtin, existente desde os anos 30. Na teoria bakhtiniana, o termo dialogismo remete à relação entre um enunciado e um conjunto de outros enunciados. Em outras palavras, qualquer sistema de signos seria atravessado por enunciados predecessores, não existindo, portanto, ineditismo na composição de novos textos. Desta feita, este conceito sugere que sempre há um ponto de interseção entre textos. Partindo, pois, da proposição de Bakhtin, Kristeva (2005: 68) inaugura o termo intertextualidade para referir-se ao processo pelo qual todo texto se constrói como mosaico de citações, todo texto é absorção e transformação de um outro texto". Similarmente à teoria de Kristeva, Genette propõe sua teoria, impactando na forma de se pensar a adaptação, sugerindo o importante conceito teórico que trata da relação entre textos.

A partir do que nos propõe Genette acerca dos cinco tipos de hipertextualidade supramencionados, destacamos que o fenômeno da re-escritura de conteúdos anteriores permite que as adaptações de textos para o cinema possam ser vistas como leituras e/ou releituras hipertextuais. $\mathrm{Na}$ atualidade, as 
discussões existentes em torno de aspectos como fidelidade ou infidelidade na diversificação dos suportes de texto constituem um discurso menos valorativo sobre intertextualidade, devido à constante e revigorante produção das transformações intertextuais, de textos que geram outros textos em favor das transformações. Partindo de tais considerações, propomos a análise da narrativa fílmica Frozen (2013) como um hipertexto, cujo texto de referência (hipotexto) é o antigo conto de Andersen, A rainha da neve (1844). Tal análise permite-nos observar as novas possiblidades de leitura suscitadas pela instância revisionista que o cinema conferiu ao conto de fada de Andersen, de modo a transgredir o convencional, mesmo que não completamente, conforme se verá adiante. Elementos encontrados em Frozen constituem uma derivação do texto de Andersen, evocados de forma tal que o conto não seja explicitamente citado. Assim, neste caso, o fenômeno da hipertextualidade dá-se, tomando de empréstimo a teoria de Genette, pela transformação, uma ação mais complexa e indireta de se retomar elementos de um texto preexistente.

A 'transformação séria', conforme expressão de Genette, ou transposição, pode se aplicar a obras de vastas dimensões, estando esta produtividade ligada à diversidade dos procedimentos transformacionais com que opera e a amplitude e variedade de procedimentos nela envolvidos. Assim, podemos observar a obra fílmica em questão recuperando, por meio de diferentes recursos estilísticos, a narrativa que se reconstitui em torno da metáfora do gelo.

\section{Era outra vez em Frozen...}

O longa-metragem Frozen (na versão cinematográfica brasileira, Frozen - Uma Aventura Congelante) é um filme de animação musical estadunidense produzido pela Walt Disney AnimationStudios e dirigido por Chris Buck e Jennifer Lee. Estreou nos Estados Unidos em novembro de 2013, tendo uma excelente repercussão e aceitação por parte da crítica especializada bem como pelo grande sucesso que alcançou junto ao público, tanto que a animação recebeu o Oscar de melhor filme de animação e melhor canção original no ano de 2014. Segundo informações veiculadas pela mídia digital, "a animação se tornou o quinto filme de maior bilheteria da história, com US\$ 1.219 bilhões em bilheteria no mundo todo" (Revista Exame 2014). Esses dados fazem de Frozen uma das produções mais bem sucedidas da Disney, sendo uma das mais vistas de todos os tempos. 
A tradição dos estúdios Disney em produzir contos de fadas vem sendo consolidada há várias décadas, de modo que é praticamente impossível falar em contos de fadas cinematográficos sem fazer menção aos clássicos da Disney que estiveram presentes no imaginário de várias gerações. De fato, a expressividade das produções de contos de fadas da Disney é tão significativa que vemos, constantemente, clássicos produzidos por este estúdio sendo desconstruídos e recombinados na cultura popular pois, seus enredos e personagens possuem reconhecimento no imaginário do público que é capaz de identificar elementos dos clássicos cinematográficos em vários outros segmentos da cultura audiovisual, como comerciais de televisão, artigos de publicidade, etc.

Contudo, não podemos deixar de mencionar aqui as inúmeras críticas que as produções dos contos de fadas da Disney receberam - e ainda recebem - diante da postura muitas vezes conservadora ao veicular concepções hegemônicas de raça, sexualidade, etnia, história e gênero, transmitindo mensagens subliminares sobre tais aspectos e reforçando estereótipos cristalizados. Todos esses elementos podem ser facilmente identificados em produções clássicas de sucesso da Disney, representando princesas de pele clara, com finas silhuetas, dotadas de uma beleza docilizada e comportamentos passivos, sempre à espera da intervenção salvífica e do amor de um homem para conferir-lhes a felicidade eterna por meio do casamento. É o que ocorre com Cinderela, Branca de Neve, Rapunzel, Bela Adormecida e tantas outras que traduziram a expressão de uma ideologia que determina papeis fixos e predeterminados para os sujeitos sociais. Embora tenhamos assistido a todas essas produções consagradas pelo público no decorrer dos tempos, há que se considerar que a evolução das sociedades e as mudanças ideológicas trouxeram algumas reflexões significativas para as produções artísticas e culturais potencialmente voltadas para o público infantil.

Nesse sentido, ressalte-se que, nas últimas décadas, não somente a Disney, mas estúdios de grande representação como a DreamWorks e a Universal Pictures têm lançado no mercado produções que parecem desvencilhar-se dos padrões tradicionais de enredo, personagens e temáticas dos contos de fadas clássicos. Referimo-nos às adaptações fílmicas ou (re) criações dos contos de fadas que possibilitam releituras que instauram novas perspectivas para se pensar muitas convicções e valores legitimados pelas histórias tradicionais. 
Dentre vários títulos expressivos nesse terreno, citemos Tangled(2011), traduzido no Brasil como Enrolados - produzido pela Walt Disney Animation Studios - que recria a história de Rapunzel, dos Irmãos Grimm, conferindo ao conto elementos da modernidade tais como a capacidade de autonomia, coragem e subversão da princesa que se empodera para libertar-se da torre e conquistar sua liberdade com astúcia e determinação. Outro exemplo de filme de animação que tem sido favorável para a multiplicação de olhares revisionistas sobre as histórias clássicas da infância são as quatro edições de Shrek (2001, 2004, 2007 e 2010), da DreamWorks, que é protagonizado pelo casal de ogros, Shrek e Fiona. Tais personagens nada têm de convencionais no que se refere a padrões de comportamento e beleza como nos contos de fadas consagrados pela tradição. Contrário a este fato, as produções supracitadas parodiam ${ }^{6}$ versões de contos clássicos suscitando novos sentidos a partir das velhas histórias.

Tantas outras obras poderiam ser citadas aqui, como a última versão que os estúdios Disney conferiram à história da Bela Adormecida, Malévola (2014), em que o protagonismo do conto fica a cargo da personagem homônima que transita entre a vilania e a heroicidade, modificando os rumos tomados pela história tradicional. Seguindo essa tendência de combinar, transformar e intertextualizar aspectos e textos clássicos, encontramos também a animação Frozen, que constitui o corpus da presente análise, instigando-nos a examinar de que modo e a que ponto seus aspectos inventivos compõem um revisionismo à obra original e apontam efeitos decorrentes da hipertextualidade, ao ser representada pela linguagem do cinema.

Mesmo tendo sua primeira edição datada de 1844 e aparecido em diversas edições desde sua publicação primeira, a história "A rainha da neve", de Hans C. Andersen, não possui o mesmo índice de popularidade que alcançaram outros contos do autor dinamarquês, a exemplo do que ocorre com "O patinho feio"; "O soldadinho de chumbo"; "A princesa e a ervilha" etc. "A Rainha da Neve" é uma narrativa extensa em que se conta a história de Ger-

6 A paródia, tal como define Genette (1982), constitui-se como uma outra prática intertextual que não se caracteriza por uma relação de co-presença no texto, mas de derivação que implica a transformação de uma obra precedente, exibindo um vínculo com a literatura existente. Nesse processo, a paródia teria uma visada mais lúdica e até mesmo subversiva, de modo que desvia seu hipotexto para ironizá-lo, tendo a variante parodística a possibilidade de ser facilmente reconhecida pelos receptores. 
da e seu irmão Kay. Estes precisam superar as adversidades provocadas pela Rainha da Neve, a vilã assim denominada, que mantém o menino refém de seu poder congelante. No percurso pela busca do irmão aprisionado, Gerda protagoniza uma aventura que envolve uma poderosa feiticeira, animais falantes e percorre terras distantes para poder restabelecer o convívio fraterno. Os acontecimentos do conto ocorrem em torno da clássica dualidade entre o bem e o mal e na perspectiva de saber se o calor da amizade pode triunfar sobre a frieza do mal (metaforizada pelo gelo) provocado pela Rainha da Neve.

Ainda que esta não seja uma história tão fortemente presente na memória da coletividade, é possivelmente a ela que o filme Frozen evoca. Muitos dos elementos do conto de Andersen reaparecem na narrativa fílmica, porém reconfigurados. Em Frozen, a rainha da neve é representada por Elsa, a mais velha de duas irmãs órfãs que crescem privadas do convívio fraterno, o que nos remete à ideia da separação vivida pelos irmãos Gerda e Kay, no conto de Andersen. Na narrativa fílmica, essa privação decorre da tentativa de evitar que Anna, a irmã ultimogênita, seja novamente atingida pelo poder congelante de Elsa, assim como ocorreu acidentalmente numa brincadeira de infância entre as duas personagens. Nesta versão, a figura da Rainha, transmutada agora em uma das irmãs, não ocupa um lugar fixo de vilania, pois, apesar de poder ocasionar o mal com seu dom poderoso, Elsa (que assume a condição de rainha ao atingir a idade adulta por ser a sucessora primeira de seus pais falecidos) não age com essa intenção, diferente do que ocorre na história predecessora, em que a rainha da neve ocupa um lugar estável no posto de vilã. Em uma perspectiva geral, constatamos que tanto a narrativa tradicional quanto a fílmica se desenvolvem em torno do mesmo cerne - a busca pelo superação de adversidades em prol da restauração de uma relação familiar. Observamos que, após anos transcorridos, uma outra nuance dessa história ressurge representada por uma linguagem diferente, uma vez que livro e filme são sistemas de comunicação diversos, para ir além da simples variação de suporte ou linguagem.

\section{Elsa, a rainha da neve}

A narrativa transposta para a tela vê-se pontilhada do que se denomina aspectos inventivos, os elementos empregados para desestabilizar nossa noção do conto de fadas previsível e suas mensagens essencialistas. Daí nossa inten- 
ção em desvelar esses elementos que ressignificam a história predecessora. Da imagem na tela acompanhada por sons, movimentos, jogos de câmera, planos e enquadramentos à significação das cenas mais emblemáticas da narrativa, vão se perfazendo os caminhos da reflexão que leva o espectador a se distanciar dos padrões convencionais dos contos de fadas. Talvez esses aspectos mais emblemáticos residam na reconfiguração dos personagens principais, que abandonam seus lugares fixos e passam a assumir perfis variados na narrativa, ocasionando a ressignificação de todo o texto.

A rainha Elsa, por exemplo, inicialmente não projeta com clareza um tipo de personagem específico e não assume uma posição fixa, preestabelecida no conto. Ao voltarmos nosso olhar para as representações de princesas de animações anteriores, nota-se que a maioria delas é definida a partir de uma série de códigos ideológicos e estéticos que concorrem para a formação de uma identidade potencial de uma mulher bondosa, amável, merecedora de admiração, confrontando-se substancialmente com a figura das vilãs. A caracterização das personagens femininas se forja, via de regra, entre os extremos do bem e do mal, constituindo uma fórmula que não se manteve intacta em Frozen. Percebemos em Elsa uma complexidade em sua personalidade que destoa da clássica princesa Disney. Ela é demonstrada com seus dilemas que envolvem questões éticas e relações de significados e sentidos que existem em seu interior. Não há que se resolver, prioritariamente, nesta história, uma questão exterior e sim interior, envolvendo uma transformação na pessoa da princesa. Ela parece atravessar a imaginária linha entre o bem e o mal na medida em que se coloca ora como a personagem fria, que evita as pessoas, inclusive a própria irmã, ora como a princesa que se exila para o bem de todos à sua volta, mas que também se cansa de sacrificar-se, resolvendo deixar seu reino no avassalador inverno que causou e partir em busca de ser quem realmente é, desprendendo-se do papel de boa menina que sempre prescreveram ao feminino.

Essa é a problemática que constitui a personalidade de Elsa - a contestação e o desejo de libertação de si mesma. Parece ser este o elemento propulsor que faz com que a personagem abandone seu posto de rainha e procure viver em universo particular, regida sob sua própria conduta, o que denotaria uma espécie de subversão ao altruísmo inerente às princesas e que tentaram incutir-lhe desde a infância. Embora não revele em sua configuração enaltecimento de alguma virtude que a torne uma figura admirável e completamente dócil, ela não configura uma pessoa má, pois pode ser vista como vítima de 
seu próprio poder incontrolável de transformar em gelo tudo que toca e do preconceito que sofreu por toda a vida por ser uma pessoa diferente. Depois de descontrolar-se emocionalmente no momento de sua coroação como rainha, Elsa deixa que seus poderes venham à tona assolando seu reino com um rigoroso inverno. A partir de então, a jovem rainha decide abandonar a todos, inclusive a irmã, e partir para uma vida solitária. Essa é a postura subversiva que a retira da condição da perfeita altruísta que se entrega ao sofrimento, e a aproxima de uma figura comum, com fragilidades. Ainda assim a personagem da rainha parece ganhar nuances que causam empatia, por mover-se com um senso de desafio a si mesma, denunciando sua grandiosidade ao enfrentar sua situação e empoderar-se diante dela, o que revela mais uma das possibilidades que vão transitando entre a princesa encantada ou a feiticeira que pode provocar o mal.

O fato de a personagem encontrar-se em tão grande dilema existencial é que desencadeia uma cena muito representativa na narrativa, dotada de um requinte de criação que demanda análise, por tratar-se de uma cena em que as técnicas da narrativa fílmica dão um sentido especial ao todo da história, fazendo suscitar seus processos de ressignificação. Para tanto, dispomo-nos a empregar aqui alguns conceitos básicos acerca da linguagem cinematográfica para compreender a articulação das imagens que o texto visual produz. Assim, ao adotarmos esta perspectiva, utilizaremos as definições de Ismail Xavier (2014) ao tratar da decupagem clássica em planos- processo de decomposição do filme - em nossas investigações.

A cena que representa a rainha Elsa deixando seu reino ocorre no início do filme e consiste em um dos momentos mais significativos da narrativa. Trata-se de uma sequência de aproximadamente três minutos e quarenta segundos reservada para representar o processo de modificação de status de Elsa. Ao passo em que a personagem surge, em plano geral ${ }^{7}$, em meio à imensidão das montanhas cobertas de neve, a câmera a acompanha, mostrando-a inicialmente em sua pequenez em meio à paisagem representada por cores frias e escuras, vagarosamente, de forma que o espectador possa ter uma perspectiva da situação da personagem que se encontra sozinha e temerosa em um lugar distante.

7 Plano Geral: em cenas localizadas em exteriores ou interiores amplos, a câmera toma uma posição de modo a mostrar todo o espaço da ação. 
Imagem 1 - $\mathrm{O}$ isolamento da rainha ${ }^{8}$

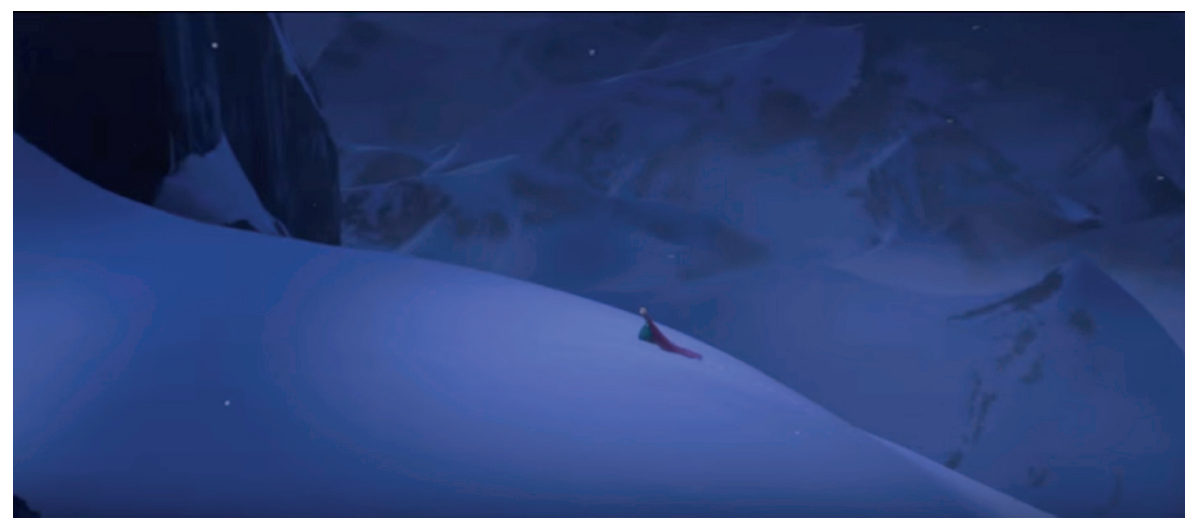

Fonte: printscreen Frozen, 2013, 32'07”

Um elemento fundamental para a composição desta cena é a música que desempenha função bastante significativa neste momento da narrativa. A canção, um recurso extremamente expressivo, fornece um forte acompanhamento emocional e integra a construção do universo que está sendo representado. Outros momentos da história são encenados por musicais, entretanto, nenhum deles parece assumir uma expressividade tão enriquecedora quanto este, pois a canção entoada por Elsa soa como um hino de sua libertação da condição de repressão sob a qual esteve por toda sua existência. Em ritmo lento, a música vai compondo a cena e sublimando a mensagem da personagem, que expressa com seu canto a incapacidade de ter de continuar se contendo, escondendo seus poderes e se resguardando num reino de isolamento.

A neve branca brilha na montanha esta noite / Nenhuma pegada pode ser vista / Um reino de isolamento / $\mathrm{E}$ parece que eu sou a rainha / $\mathrm{O}$ vento está uivando / Como se essa tempestade rodopiasse dentro de mim / Não consegui segurá-la / Os céus sabem que eu tentei / Não os deixe entrar, não os deixe ver / Seja a boa menina que você sempre precisou ser / Esconda, não sinta, / Não deixe que eles saibam / Bem, agora eles sabem! [...] (Lopez; Lopez 2013, tradução nossa).

8 As imagens utilizadas neste trabalho são de caráter ilustrativo e estão sendo utilizadas exclusivamente para fins acadêmicos. Todas tratam-se de printscreen da animação. Os direitos autorais estão reservados aos estúdios Disney Pictures.

9 The snow blows white on the mountain tonight / Not a foot print to be seen / A kingdom of isolation / and it looks like I'm th equeen / The windishowling / like the swirlings torm inside / Couldn'tkeep it in / Heavenknows I try / Don't let them in, don't le them see / Be the good girl you always had to be / Conceal, don't feel, don't let them know / Well now they know [...] (Lopez; Lopez 2013). 
Há, neste momento, um enquadramento da rainha que tem seu sentimento de tristeza enaltecido pelo foco da câmera em close $^{10}$, em sua postura cabisbaixa e seu semblante de tristeza.

Imagem 2 - A tristeza da rainha

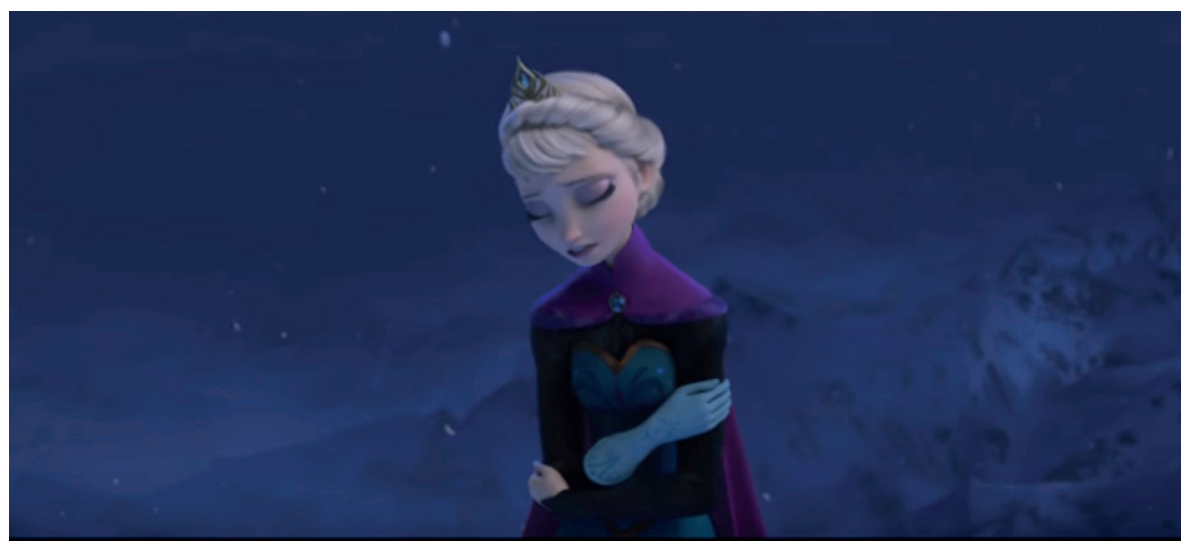

Fonte: printscreen Frozen, 2013, 32'42”

Entretanto, à medida em que a rainha caminha sobre a neve, uma mudança de perspectiva acontece, denotada pelo ângulo da câmera que a acompanha, em plongeé $e^{11}$ dando foco na retirada da luva que cobria suas mãos para impedir que a neve fosse lançada, simbolizando que a repressão e a omissão de seus poderes estavam sendo rompidas, jogadas para o alto, tal como na cena.

Imagem 3 - Quebrando as amarras

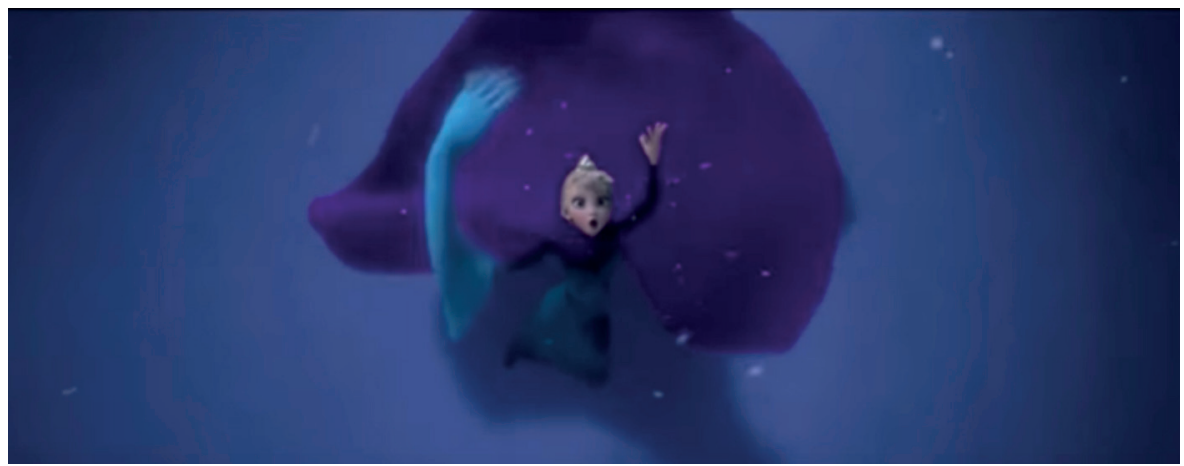

Fonte: printscreen Frozen, 2013, 33’01”

10 Close: Foco, imagem aproximada em um ponto específico do enquadramento.

11 Plongeé: ou câmera alta, representa a imagem de cima para baixo. 
O compasso da canção recebe neste momento um ritmo mais acelerado e sugere um tom subversivo com relação à aceitação das condições que sempre lhe foram determinadas. "Deixe pra lá, deixe pra lá / Não posso suportar mais / Deixe pra lá, deixe pra lá / Dou as costas e bato a porta / Eu não me importo / Com o que eles vão dizer / Deixe a tempestade rugir / O frio não vai mesmo me incomodar [...]" (Lopez; Lopez 2013, tradução nossa) ${ }^{12}$. A referência ao frio que não vai mais incomodar denota que, estando longe das pessoas, seu poder está liberto e não será mais motivo de incômodo. Ressalta-se agora a aceitação que a rainha parece ter de si mesma. Ao cantar essas palavras, há uma demarcação da ruptura com a vida contida que a jovem levava até então. Este fato fica expresso na sequência da cena que é filmada agora em plano americano ${ }^{13}$, para dar ênfase à retirada da capa que envolve seu corpo e é jogada ao vento, uma ação que representa não só o desfazer-se da aparência pudica da jovem rainha, mas o enaltecimento da pessoa que há em seu interior.

Imagem 4 - O início da transformação

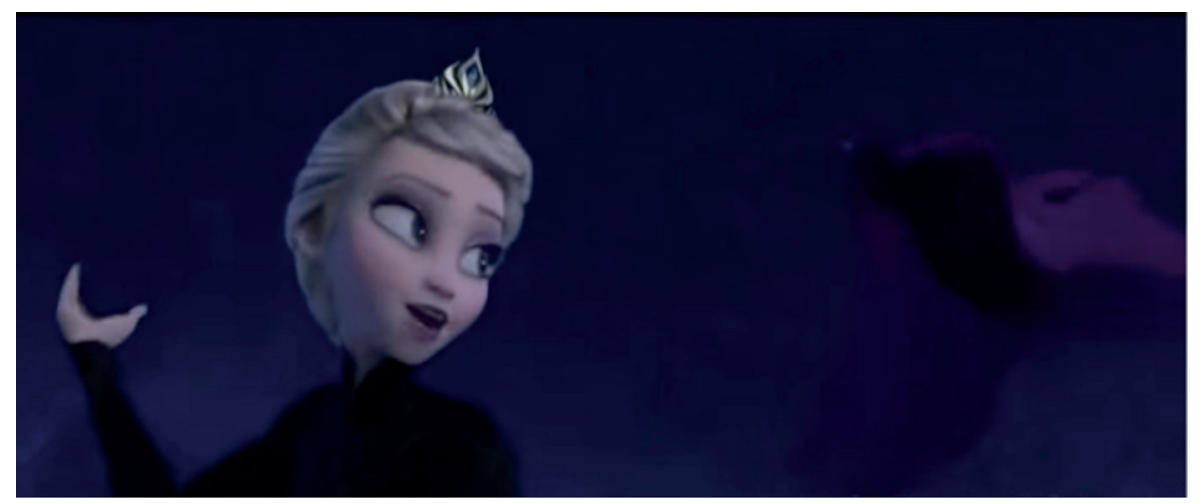

Fonte: printscreen Frozen, 2013, 33’42”

A tiara, simbologia maior do figurino de rainha, também é desprezada, revelando que a personagem quer desvencilhar-se totalmente do que representou até então. Todo seu visual vai sendo modificado. A cena continua a ser desenvolvida demonstrando a transformação da personagem que já assume uma postura firme, um caminhar mais determinado à medida em que canta

12 Let it go, let it go / Can't hold you back anymore / Let it go, let it go /Turnmy back and slam the door /And here I stand /And here I'll stay / Let it go, let it go /The cold never bothered me anyway (Lopez; Lopez 2013).

13 Corresponde ao ponto de vista em que as figuras humanas são apresentadas da cabeça até a cintura, aproximadamente. 
"É tempo de ver o que eu posso fazer / Testar os limites e transpô-los / Sem certo, sem errado / Sem regras para mim / Livre estou! Livre estou! [...]" (Lopez; Lopez 2013, tradução nossa) ${ }^{14}$. Ela aparece agora com os cabelos trançados, porém sem estarem rigorosamente presos e usando um vestido de cores menos sombrias, que remetem às cores do gelo e da neve, denotando um tom de sensualidade, atitude de quem quer se revelar.

\section{Imagem 5 -Auto revelação}

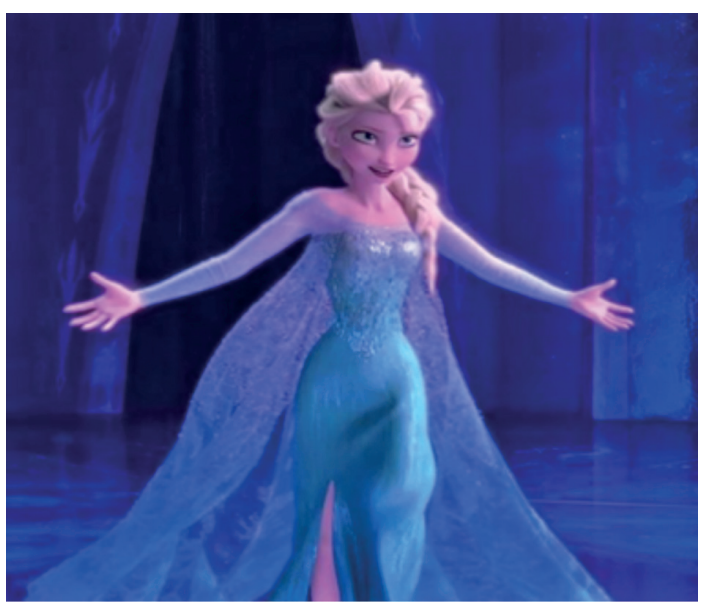

Fonte: printscreen Frozen, 2013, 35'08”

Mais uma vez há um foco em seu rosto, captado pela câmera em primeiro plano, com close na expressão de tranquilidade e no sorriso que esboça satisfação e liberdade.

Imagem 6 - A autonomia da rainha

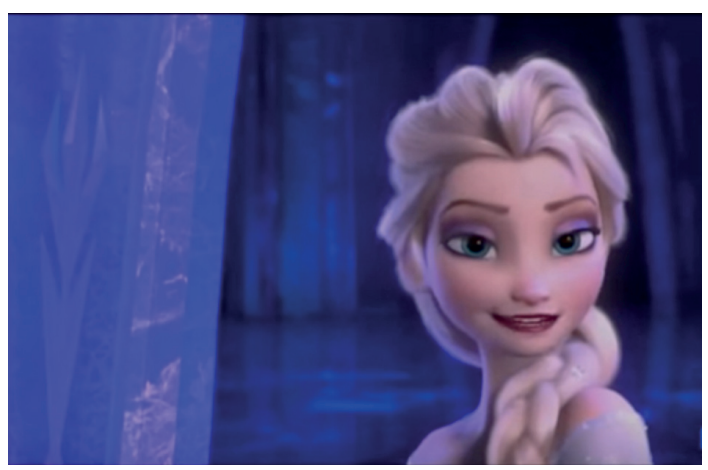

Fonte: printscreen Frozen, 2013, 35'12"

14 It's time tosee what I can do / Test the limits and transpose them / Without certain, without wrong / Withou trules for me / Free I am! I am free! 
Em câmera subjetiva ${ }^{15}$, Elsa admira suas criações com a neve, que agora está sob seu comando e, diante disso, encoraja-se a criar seu próprio castelo, uma belíssima escultura de gelo, apresentada em plano geral para expressar a magnitude de sua criação.

Imagem 7 - A fortaleza de gelo

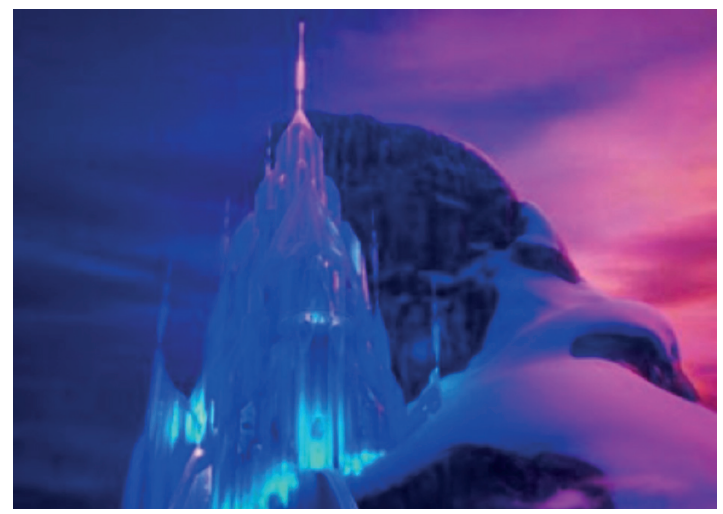

Fonte: printscreen Frozen, 2012, 35’16”

Esta cena é finalizada com a rainha adentrando seu castelo de gelo e fechando com veemência suas portas, exilando-se, abstendo-se da interação com o exterior. Simultâneo ao fechar das portas é o fim da canção, que termina encerrando o ciclo que, conforme canta a rainha, não terá mais o frio a incomodar.

\section{Vossa majestade, a princesa Anna, e sua (des)construção}

Nessa mesma perspectiva em que os personagens da narrativa fílmica assumem aspectos inventivos em sua configuração encontramos também a princesa Anna. A segunda princesa de Frozen apresenta características que constituem verdadeira desconstrução de padrões que envolvem o perfil de uma princesa Disney. Anna é apresentada em uma esfera humorística, denotando seu caráter divertido e seu estilo desajeitado, sem a pompa que caracterizava as princesas clássicas de outrora. A nuance contraditória ao padrão empregado no delineamento desta personagem nos remete, mais uma vez,

15 A câmera é dita subjetiva quando assume o ponto de vista de uma das personagens, observando os acontecimentos de sua posição com seus olhos. 
ao arcabouço teórico desenvolvido por Genette a respeito da derivação de textos, mais especificamente em sua referência à paródia. Ao conceder à princesa características de simplicidade, ressalta-se seu caráter mais humanitário, dotado de imperfeições. Isso promove um distanciamento crítico, possibilitando que a personagem da princesa, redefinida fora do padrão costumeiro, seja vista de maneira alternativa ao estereótipo enrijecido, principalmente no tocante à personagem. Embora a visada da paródia seja, conforme salienta Genette, lúdica e subversiva, essa forma de construção opera como importante propulsor de questionamento em torno do convencional. O contraste existente entre a forma predecessora de princesas e a forma parodiada faz com que novos significados possam emergir a partir das transformações.

A primeira cena da princesa Anna no filme, em idade adulta, explicita as características que demonstram seu lado mais 'humano' por ser 'imperfeito', contrastando explicitamente seu perfil com a perfeição representada nas princesas clássicas. Anna aparece sendo acordada por seu mordomo, no importante dia em que ocorrerá a coroação de sua irmã. Nesta cena inicial, o rosto de Anna aparece sob foco em primeiro plano de modo que se notabilize seu estilo despojado, de cabelos despenteados e lábios entreabertos pelos quais perpassam ruídos provocados pelo ronco da personagem, antes de se levantar.

Imagem 8 - Princesa Anna

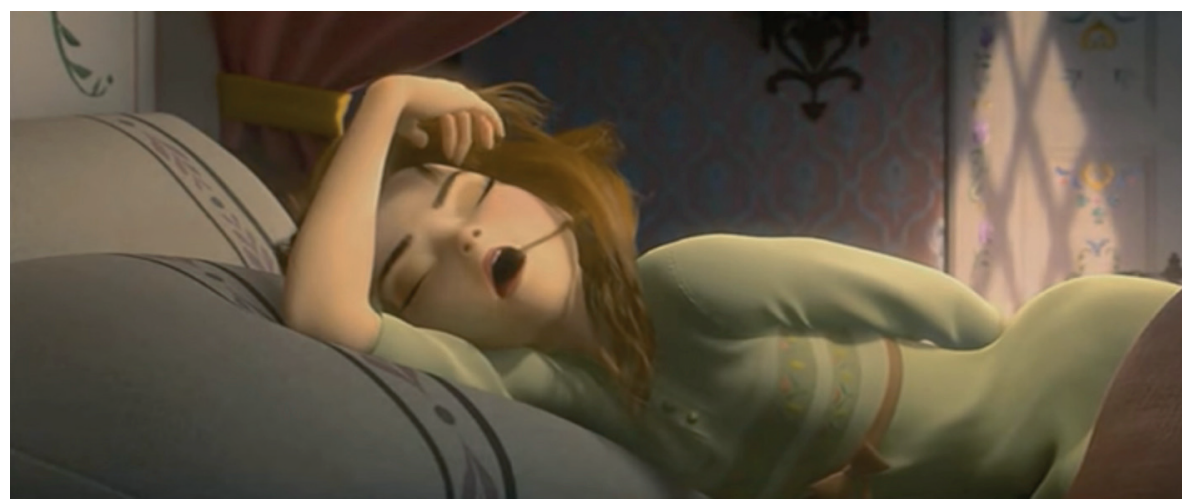

Fonte: printscreen Frozen, 2013, 13'33”'

Esta cena, que demonstra uma princesa em aparência nada majestosa, concorre na narrativa justamente para explicitar a normalidade da personagem, possibilitando a abertura para que haja um diálogo entre o que se assiste e as mais corriqueiras realidades das pessoas. Outro elemento interessante 
desta sequência é o foco na mecha de cabelos brancos que a princesa possui, que aparece de forma bem enaltecida no momento em que o rosto da jovem é enquadrado. Essa mecha simboliza a ausência de vida provocada pelo gelo que a atingiu, lançado acidentalmente por sua irmã, ainda na infância. Mesmo depois que a princesa se compõe e prende os cabelos, a mecha de fios brancos continua perceptível, de modo que sua simbologia esteja presente em toda a narrativa e reforce o motivo pelo qual as irmãs são privadas de convívio.

Imagem 9 - Marcas do passado

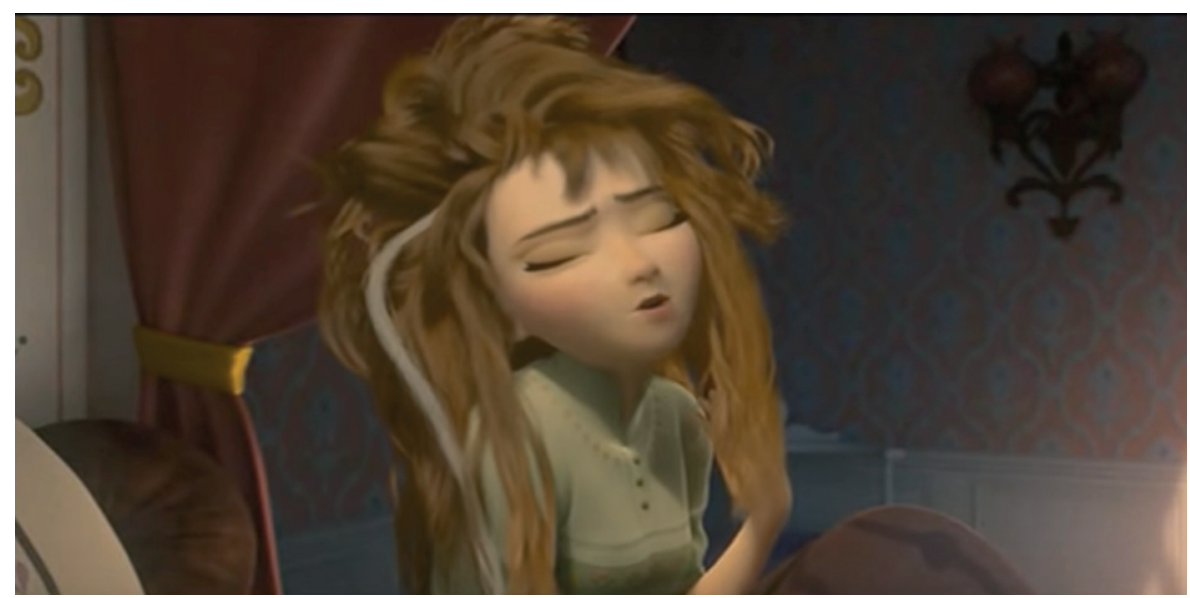

Fonte: printscreen Frozen, 2013, 13'40”

Nos momentos iniciais da atuação de Anna, sua postura parece remeter a de uma princesa ingênua, que acredita em amor à primeira vista. Ela acredita estar apaixonada pelo belo príncipe Hans, que aparece para o baile da coroação. Contudo, à medida em que se dão os acontecimentos, a jovem princesa compreende que seu relacionamento é uma causa secundária em seu caminho. Sua meta seria encontrar a irmã, que acabara de sair de seu reino, e tentar uma reaproximação para que, além de libertar o reino do aspecto desolador do inverno, pudesse desfazer o profundo distanciamento que as afastava. No intento de cumprir seu objetivo, Anna vai revelando astúcia, perseverança, inteligência e esperteza à medida em que providencia os meios para encontrar sua irmã e não se tornar apenas uma jovem princesa indefesa diante dos perigos do ambiente congelante no qual se aventura.

Ao analisarmos como os personagens são reinventados na narrativa fílmica, nos chama a atenção também a configuração do príncipe agregado a esta 
versão. Hans ocuparia o lugar de 'príncipe encantado' num conto de fadas clássico, porém, em Frozen, este personagem é inserido na trama para operar como agente de desconstrução da ideia recorrente nos contos de fadas de que um príncipe sempre trará à princesa a resolução de seus conflitos e a conduzirá à felicidade eterna após conceder-lhe um beijo de amor verdadeiro. O que nos autoriza inferir que este personagem não aparece na animação gratuitamente é a negação que ele fará ao seu papel salvífico, caracterizando assim um outro aspecto em que a história é reinventada em favor da desconstrução de valores preestabelecidos. Mais uma vez observamos o caráter parodístico empregado na narrativa. A figura do personagem heróico é invertida, de modo a contestar o padrão do clássico e encantado príncipe, acionando o caráter transformador inerente à paródia.

Hans aparece no reino de Arendelle para a festa da coroação da rainha Elsa e conhece Anna, por quem se diz apaixonado à primeira vista. Entretanto, à medida em que a narrativa se desenvolve, o simpático príncipe que aparenta ser bondoso e interessado em ajudar sua pretensa futura esposa Anna, se revela, em um momento crucial da narrativa, exatamente o oposto do que parecia ser. É este personagem que desestabiliza a ordem comum dos acontecimentos ao revelar que se aproximou da jovem princesa apenas para se tornar parte da realeza de Arendelle e tomar este reino para si. Este príncipe subverte o estereótipo do homem corajoso e salvador e ao mesmo tempo desconstrói a prerrogativa do amor à primeira vista tão comum nos contos de fadas. Diante dessa negação de amor, outro fator importante é desencadeado na trama. Há um segundo acidente entre Elsa e Anna deixando essa última no limiar da morte, por ter sido atingida com a frieza da neve no coração, que somente poderá ser reestabelecido ao ser aquecido por um ato de amor verdadeiro. A composição da cena que representa este momento de tensão na narrativa assume função bastante representativa no contexto geral da história pois, conforme mencionamos, trata-se de um instante de tensão em que os acontecimentos tomam rumos surpreendentes e não aqueles previamente esperados.

Toda a mudança de perspectiva da história é explicitada na criação da cena que é iniciada em plano médio, de modo que se notabilize Hans e Anna, que acaba de retornar ao castelo bastante fragilizada pelo gelo que está tomando conta de todo seu corpo, ceifando sua vida. Há um foco nos dois personagens quando Anna revela que seu coração foi congelado e só um beijo de amor verdadeiro poderá salvá-la. O foco no rosto de ambos denota, então, o sem- 
blante de sofrimento da princesa esperançosa e a expressão do príncipe que sugere perversidade.

Imagem 10 - A revelação de Hans

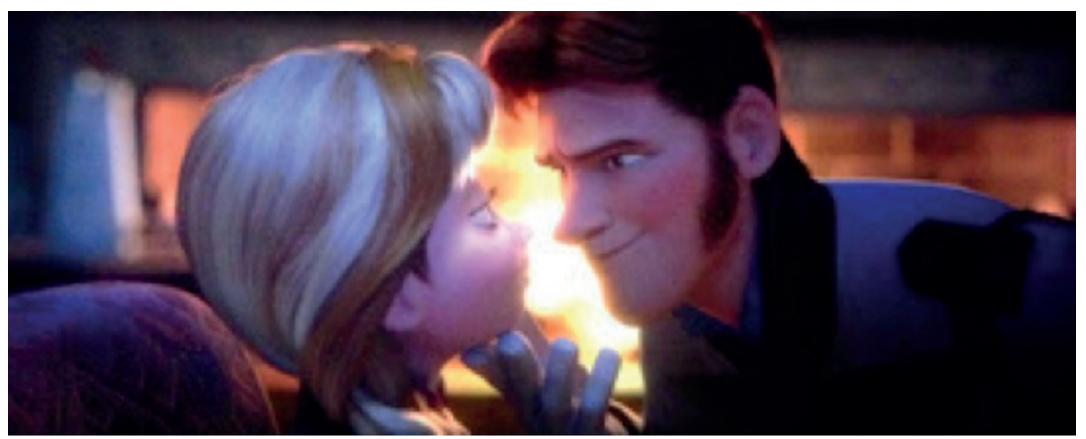

Fonte: printscreen Frozen, 2013, 76'56"

Ainda enquadrados em primeiro plano e com close nas faces dos personagens, espera-se que a tradicional cena do beijo de amor verdadeiro seja consolidada naquele momento. Há uma música romântica ao fundo, os rostos 64 estão próximos, os olhos se fecham e os lábios se aproximam, porém, não se tocam. A música é interrompida e então, imediatamente, o foco se volta para a face do príncipe que tem seu movimento acompanhado em câmera subjetiva, sob a perspectiva dos olhos desesperançosos da princesa fitados no príncipe que a surpreende. Com ares de cinismo e tendo enaltecida a expressão de rudeza, o príncipe revela, agora enquadrado frente a frente com a princesa, que não a ama e tratará de findar com a vida de Elsa para consolidar seu golpe e se tornar governante de Arendelle.

Imagem 11- A consolidação do golpe

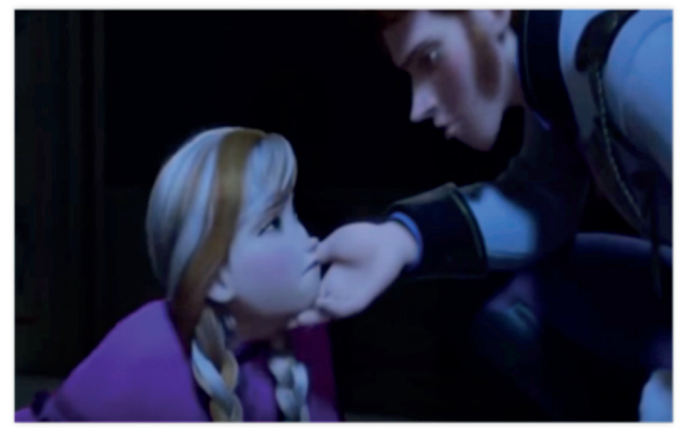

Fonte: printscreen Frozen, 2013, 77'10" 
A representação de um príncipe anti-herói nesta narrativa suscita outro ponto relevante para o desfecho da história. É em função da negação do amor à princesa que se tem a desconstrução da ideia de amor redentor entre homem e mulher e ressalta-se a ideia de que o amor, para ser verdadeiro, não precisa partir exclusivamente de um casal. Assim como ocorre no conto de Andersen, em que Gerda enfrenta desafios vários em busca de Kay até encontrá-lo e suscitar as lembranças que trazem de volta o amor ao coração do jovem, salvando-o do frio perene em seu coração, em Frozen o amor verdadeiro também tem o poder da salvação, porém, partindo de uma irmã para a outra e do enfrentamento das adversidades que se apresentam a ambas.

\section{Histórias pretéritas, perspectivas futuras}

Observamos até aqui que Frozen traz novas nuances para a história regida em torno da metáfora do gelo, demonstrando que significativas mudanças estão ocorrendo no mundo dos contos revisitados que se voltam para o imaginário infantil. Conforme ponderam Burlamaque e Zannata,

Se muitos aspectos mudaram no mundo da fantasia, o que se atrelava ao enredo era seu nível complicado de desenvolvimento, enquanto suas personagens apenas seguiam fielmente o destino reservado a elas de acordo com a trajetória da narrativa. $\mathrm{Na}$ era contemporânea, são as personagens que dão vida e voz ao enredo, tornando-se fundamentais para a existência do mesmo, uma vez que além de conduzirem a história, as personagens rompem a tradição, destacando as jornadas subjetivas que enfrentam rumo ao desfecho da ação (Burlamaque \& Zanata 2012: 89).

Em se tratando de narrativas de fadas ou maravilhosas, o que podemos observar, de maneira comum, é a recorrência aos padrões. No que se refere à representação da figura feminina, por exemplo, salta aos olhos o perfil dócil, passivo, subordinado com que as mulheres são representadas:

Nos contos denominados <<de fadas $>>[. .$.$] no que pese o lugar de protagonista$ que a julgar pelos títulos dos contos pode se lhe outorgar, a mulher sempre aparece com uma condição subordinada ao homem, e [...] o culto ao amor que neles se descreve não é outra coisa que a sublimação desta subordinação: o cavalheiro faz tudo por sua amada, e esta, por sua vez, encontra-se apaixonada por seu herói ${ }^{16}$.

16 Tradução nossa para: "En los cuentos denominados <<de hadas >>, [...] pese al lugar protagonista que a juzgar por los títulos de los cuentos pudiera otorgársele, la mujer siempre aparece con una condición supeditada al hombre, y que el culto al amor que en ellos se describe no es outra cosa 
Ao acionar uma narrativa preexistente, transformando-a, conforme acepção genettiana, o longa-metragem Frozen revela mudanças substancias que concorrem para a subversão de padrões habitualmente seguidos: atos de amor verdadeiro que não se resumem em um mero beijo entre pessoas que se amaram à primeira vista; mulheres protagonizando histórias e assumindo a condição de heroínas corajosas e ao mesmo tempo sensíveis e, com isso, representando a descentralização do poder protagonizado pela masculinidade. Todos esses elementos se tornam constituintes de um enredo que, através de suas problemáticas e ações mais coerentes com a vida e com o cotidiano, rompem com ideologias cristalizadas e apresentam uma construção instigante que concilia humor, emoção e subversão, distanciando-se do tradicionalismo disciplinante dos velhos contos de fadas.

A existência de duas princesas no filme imprime mais um exemplo de rompimento com o que comumente se apresenta nos contos de fadas. São duas protagonistas em favor de demonstrar as diferenças de personalidades das pessoas, bem como suas particularidades e preferências. Elsa percorre toda sua trajetória sem esperar por um herói que intervenha em seus conflitos. Nenhum par romântico aparece para a rainha, que termina a narrativa desmitificando o 'feliz para sempre' após o casamento. Em contrapartida, o amor acontece para Anna, entretanto, também desconstruindo o 'amor à primeira vista' e demonstrando a valorização aos sentimentos que podem surgir fora do estereótipo príncipe / princesa, pois é um simples vendedor de gelo, por sinal desprovido de beleza física e encantos inerentes aos príncipes idealizados, que inicia um relacionamento amoroso com Anna e a auxilia em sua jornada. Ressalte-se que este relacionamento não marca o fim da narrativa nem traz consigo a representatividade da felicidade advinda do matrimônio. Ele parece existir muito mais para denotar que o amor pode acontecer entre pessoas de classes e estilos completamente diferentes, e é construído com o tempo e não no ímpeto do primeiro encontro, tal como se representa por tantas vezes nos contos de fadas.

O final da história acontece trazendo à tona a clássica cena do beijo salvador, no entanto, entre as princesas. Não só o beijo, mas o abraço afável, o choro pela perda, o amor que aquece o coração funcionam, nesta narrativa, 
como conotação do sentimento de fé e amor, representando que a verdadeira magia está na capacidade de acreditar e amar. Esta é outra sequência digna de atenção no texto fílmico e que também estabelece uma relação de sentido no que se refere ao processo de revisão do texto original. Nestes planos, a escolha do tipo de relação entre imagens e sons concorre para atribuir mais ênfase à cena que, iniciada em plano médio, representa a morte iminente de Anna. Poucas palavras são ditas pela princesa, apenas o uivo do vento é enaltecido nesse momento. Closes vão evidenciando a pele quase completamente congelada de Anna e seus passos titubeantes em meio à forte tempestade de neve. A fotografia desta cena revela uma preocupação da produção em enriquecer o processo de representação utilizando-se de cores frias e opacas (cinza, branco, azul claro) para transmitir a sensação do momento e a ideia de que o gelo, o frio e a neve estariam tomando conta de todo o cenário, inclusive da princesa Anna, conforme demonstra o foco dado em suas mãos, conferindo ênfase ao iminente congelamento da princesa.

Imagem 12 - O princípio do congelamento

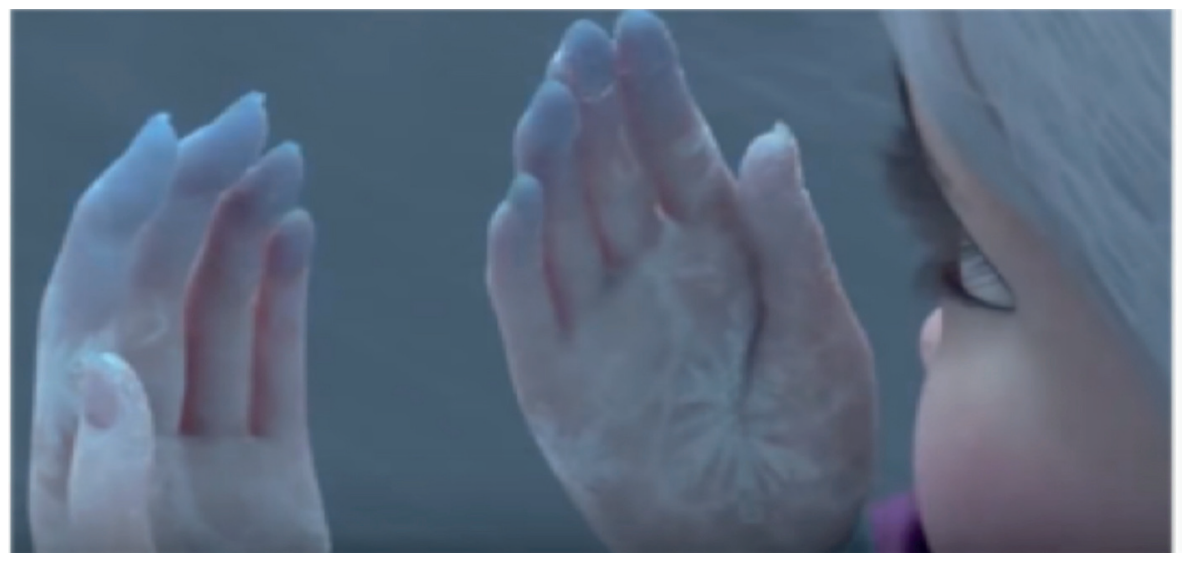

Fonte: printscreen Frozen, 2013, 84'58”

Contudo, há uma mudança de perspectiva nesta sequência no momento em que Anna visualiza Elsa caída ao chão, chorando por acreditar que havia provocado a morte da irmã. Neste mesmo momento, tem-se o ápice da sequência que expressa o sacrifício da rainha, que deixa seu castelo de gelo e volta ao espaço de vulnerabilidade e insegurança de Arendelle pela irmã que, por sua vez, também se sacrifica pela rainha colocando-se à frente da lâmina da espada que Hans lança sobre Elsa. Essa representação é constituída no en- 
quadramento dos personagens, enfatizando o momento de tensão. A sequência é retomada em primeiro plano de modo a notabilizar a última ação de Anna, que se coloca diante da espada no intento de poupar a irmã da morte.

Imagem 13 - Anna em defesa de Elsa

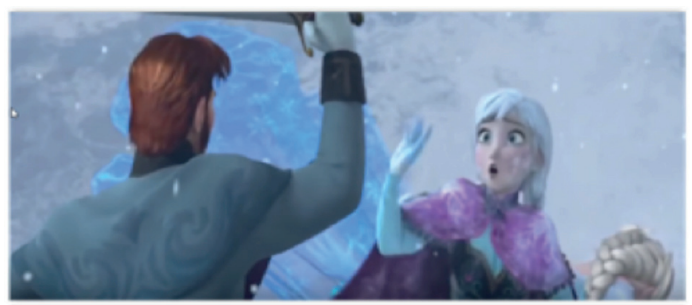

Fonte: printscreen Frozen, 2013, 87'03”

A cena passa a ser filmada então em câmera lenta, cujo ângulo gira ao longo do eixo vertical em movimento de panning (imitação do movimento dos olhos do espectador enquanto examina a cena ao seu redor). Essa preocupação do cineasta em rodar a cena sob este movimento denota o ponto de vista da personagem, neste caso a princesa, que vê a aproximação da espada e ergue seu braço que se congela rigidamente por inteiro, fazendo se partir a lâmina da espada.

A partir deste momento, o som traduz-se apenas em estilhaços de metal e o foco da sequência volta-se para a princesa completamente congelada. No silêncio da cena em que se enquadra a estátua de gelo, emerge o som do choro da rainha, o que conclui a sequência de tensão nos momentos finais da narrativa. A sequência continua sendo filmada em plano médio, de modo a enfatizar a imagem da rainha abraçando a irmã congelada e lhe afagando, por um ato de amor verdadeiro, de altruísmo e doação.

Imagem 14 - Congelamento final

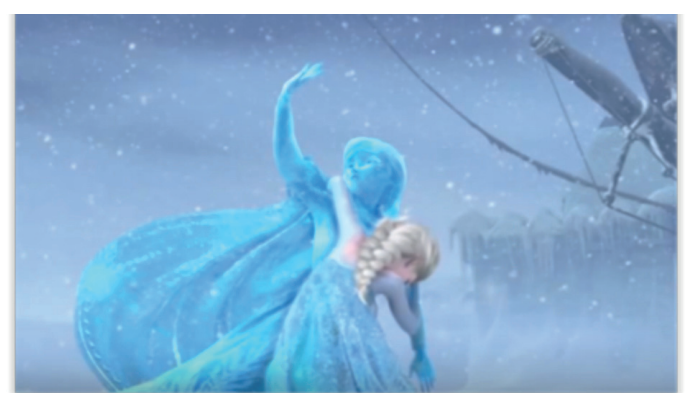

Fonte: printscreen Frozen, 2013, 87'20" 
É nesta representação que reside o ato de amor verdadeiro que descongela o coração da jovem princesa, que pelo amor de sua irmã, volta à vida. Finalmente a união das personagens é retomada, selada pelo abraço que parecia estar perdido desde a infância, quando da separação de ambas.

\section{Imagem 15 - $\mathrm{O}$ ato de amor verdadeiro}

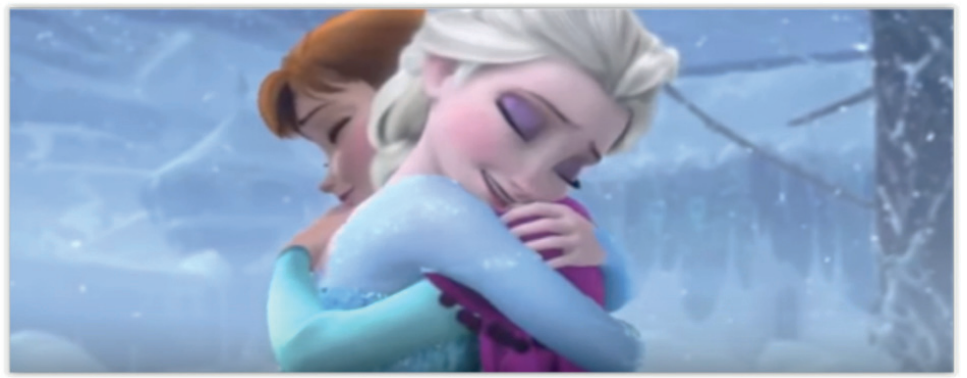

Fonte: printscreen Frozen, 2013, 88'02”

A rainha da neve, que passa por todo este processo de aceitação de si mesma, alcança o controle de seus poderes e retoma a vida em seu reino, junto aos seus, trazendo de volta para si e para seu reino o fim do rigoroso inverno a que estavam submetidos, metaforizado pela falta de amor.

\section{Então, era outra vez...}

Esse breve trajeto que percorremos acerca da narrativa analisada neste trabalho, constitui um ponto de partida para que possamos aguçar, cada vez mais, nossos e outros olhares analíticos à luz da temática revisionista do gênero conto de fadas e sua abordagem cinematográfica. As reflexões desenvolvidas são vias para que possamos pensar as potencialidades do texto literário que envolve questões para além da estética, contemplando as conexões estabelecidas entre fantasia e realidade através da ficção. Sobrepondo os limites das comparações entre uma arte e outra, literatura e cinema se entrecruzam em favor do imaginário de modo que nós, leitores / espectadores, possamos perceber, a cada nova leitura, diferentes nuances e perspectivas através das ressignificações hipertextuais. É o que faz, com que as histórias sejam contadas outra vez, de modo que a palavra outra esteja empregada para expressar o seu sentido literal - de significar o diverso, o diferente, o distinto. 
A narrativa fílmica abordada neste estudo pode ser vista como um aceno em potencial para que, através da releitura de contos de fadas, possam se instaurar novas perspectivas sobre aspectos como a representação em torno da feminilidade e masculinidade, a desconstrução de estereótipos e ideologias em torno das relações interpessoais e o modo como nós, seres humanos, somos constituídos por sentimentos vários. Conforme elucida Martins (2015), revisões podem possibilitar ao público a reflexão sobre histórias que se cristalizaram na tradição dos contos de fadas, de forma a repensar muitas convicções e valores ratificados por elas. Por assim pensarmos, acreditamos estar diante de um cinema hollywoodiano que, embora ainda tenha muito a progredir, esteja trilhando os primeiros passos na retirada de suas personagens de lugares rigidamente marcados, libertando-as de papeis sociais engessados e operando com um discurso contraideológico, em lugar de ratificar ideologias preconcebidas. A Disney, responsável por produções de grande repercussão, não poderia ficar imune às transformações sociais da contemporaneidade. Embora saibamos que há um interesse comercial por trás dessa possível reconfiguração das personagens, a representação de aspectos como os que suscitamos nesta análise se torna relevante porque essas narrativas contribuem para a formação de subjetividades das crianças, ajudando na formação de pessoas mais respeitosas e livres de preconceitos estabelecidos em razão de questões que envolvem estigmas, lugares e papeis para homens e mulheres que acabam objetificando seres humanos, já que somos seres culturais, portanto, somos construídos conforme os valores desta cultura.

Antes de encerrarmos nossas considerações, sem contudo ter a pretensão de esgotar as possibilidades de pensamentear as diferentes nuances que envolvem o tema, há que se ressaltar o lamentável fato de que, "por alguma estranha razão, os críticos de cinema e teóricos têm prestado pouca atenção no conto de fadas, e mais especificamente, no filme de contos de fadas" (Martins 2015: 286). Temos ciência de que, embora a literatura infantil tenha sido considerada uma instância menor por muitos estudiosos e críticos no decorrer de sua trajetória, é sua manifestação que opera como fonte inspiradora e formadora há muitos anos, reunindo sabedoria e manifestações de cultura através do fantástico e do maravilhoso. Antônio Candido, crítico e teórico literário, considera a literatura como componente dos direitos humanos, já que, segundo o autor, a arte literária exerce franca função humanizadora. Se uma sociedade justa pressupõe o respeito aos direitos humanos, conforme assevera Candido (1988: 191), "a fruição da arte e da literatura em todas as 
modalidades e em todos os níveis é um direito inalienável". Conforme ressaltamos inicialmente, não é nosso objetivo medir o que é mais ou menos importante ao nos referirmos à literatura e seus desdobramentos e suportes. Apropriamo-nos aqui da referência que fizemos a Jameson (1985), para confirmarmos nosso interesse no que fundamentalmente caracteriza nossa era o hibridismo das linguagens, as interfaces entre os diferentes meios, em que a pós-modernidade nos proporciona vivenciar um mundo de possibilidades que se recombinam incessantemente fazendo, por exemplo, dos filmes, um lugar de contestação de significados, delineando assim, um terreno alternativo para o gênero contos de fadas. Então, que se contem e recontem outras e outras vezes...

Fernanda L. de Oliveira Santos Silvana Augusta Barbosa Carrijo Universidade Federal de Goiás - Regional Catalão (Brasil)

\section{Referências Bibliográficas}

Andersen, Hans Christian. 1981. "A Rainha da Neve". In Contos de Hans Christian Andersen. Tradução Silvia Duarte. Rio de Janeiro: Paz e Terra, pp. 263-299.

Burlamaque, Fabiane Verardi; Zanatta, Deisi Luzia Zanatta. 2012. "Entre cinema e literatura: Rapunzel em nova roupagem". In Conto e reconto: das fontes à invenção. (Org. Vera Teixeira de Aguiar e Alice Áurea Penteado Martha). São Paulo: Cultura Acadêmica, pp. 81-92.

Candido, Antônio. 1988. "O direito à literatura”. In Vários escritos. São Paulo: Duas Cidades, pp. 169-191.

Genette, Gèrard. 2006. Palimpsestos a literatura de segunda mão. Tradução Luciene Guimarães e Maria Antônia Ramos Coutinho. Belo Horizonte. Faculdade de Letras. [Edição original: Genette, Gèrard. Palimpsestes: La littérature au second degré. Paris: Éditions du Seuil, Points Essais, 1982].

Herrero, Beatriz Fernández. 1993. "Blancanitos y las siete enanieves (Cómo educar las actitudes no sexistas a través de los cuentos)”. In Anais do Simpósio Internacional Muller e Cultura (Coordenação Aurora Marco). Santiago de Compostela: Universidade de Santiago de Compostela, pp. 307-321. 
Jameson, Frederic. 1985. "Pós-modernidade e sociedade de consumo". In Novos Estudos Cebrap, 12, pp. 16-26.

Kristeva, Julia. 2005. Introdução à semanálise. Tradução Lúcia Helena França Ferraz. São Paulo: Perspectiva. [Edição original: Kristeva, Julia. Recherches pour une sémanalyse. Editions du Seuil, 1969].

Lopez, Kristen e Robert Lopez. 2013. Original CD Songs Frozen - Disney.

Marinho, Carolina. 2009. Poéticas do maravilhoso no cinema e na literatura. Belo Horizonte: Autêntica Editora. PUC - Pontifícia Universidade Católica de Minas Gerais.

Martins, Maria Cristina. 2015. (Re)Escrituras: Gênero e o Revisionismo Contemporâneo dos Contos de Fadas. Jundiaí - SP: Paco Editorial.

Redação Revista Exame. 2014. Frozen se torna o $5^{\circ}$ filme de maior bilheteria da história, 27 mai 2014, http://exame.abril.com.br/estilo-de-vida/noticias/frozen-se-torna-o-5o-filme-de-maior-bilheteria-da-historia [Acesso em: 18 mar 2016].

Stam, Robert. 2003. Introdução à teoria do cinema. Tradução Fernando Mascarello.

72 Campinas - SP: Papirus. [Edição original: Stam, Robert. Film theory: an introduction. Malden, Mass: Blackwell, 2000].

Xavier, Ismail. 2014. O discurso cinematográfico: a opacidade e a transparência. Campinas - SP: Paz e Terra.

\section{Filmografia}

Frozen - Uma Aventura Congelante. Direção: Chris Buck, Jennifer Michelle Lee. Produção: Walt Disney Animation Studios, 2013. 102 min.

Malévola (Maleficent). Direção: Robert Stromberg. Produção: Linda Woolverton. Walt Disney Pictures, 2014. $97 \mathrm{~min}$.

Shrek Forever After. Direção: Mike Mitchell. Produção: Gina Shay e Teresa Cheng. DreamWorks Animation, 2010.93 min.

Shrek II. Direção: Andrew Adamson, Kelly Asbury e Conrad Vernon. Produção: Aron Warner, John H. Williams, David Lipman. DreamWorks Animation, 2004. $93 \mathrm{~min}$. 
Shrek The Third. Direção: Chris Miller. Produção: Aron Warner, Andrew Adamson e Denise Nolan Cascino. DreamWorks Animation, 2007.93 min.

Shrek. Direção: Andrew Adamson. Produção: Jeffrey Katzenberg, Aron Warner e John H. Williams. DreamWorks Pictures, 2001. 90 min.

Tangled. Direção: Byron Howard e Nathan Greno. Produção: Roy Conli, John Lasseter e Glen Keane. Walt Disney AnimationStudios, 2010. 100 min. 